\title{
Polemiki
}

\section{O intencjach, przypisach i przy-pisywaniu (w odpowiedzi Danucie Szajnert)}

Paweł Wolski

TEKSTY DRUGIE 2016, NR 6, S. 440-448

DOI: $10.18318 /$ td.2016.6.27

O d momentu ukazania się mojej książki Tadeusz Borowski-Primo Levi.Prze-pisywanie literatury Holocaustu' minęły już ponad trzy lata. Tym bardziej cieszy mnie więc, że dyskusja wokół niej trwa do dziś. Ostatnio, w niewielkim odstępie czasu, ukazały się bowiem dwa ważne dla mnie jej omówienia: Aleksandry Ubertowskiej i Danuty Szajnert ${ }^{3}$. Drugie z nich, polemiczne, warte jest dłuższego komentarza.

Stwierdziwszy, że „W książce Tadeusz Borowski - Primo Levi.Prze-pisywanie literatury Holocaustu nie brakuje miejsc fascynujących, trafnych rozpoznań aktualnej sytuacji tej literatury, wnikliwych obserwacji" (240), Szajnert pisze:

1 P. Wolski Tadeusz Borowski - Primo Levi: prze-pisywanie literatury Holocaustu, Stowarzyszenie Pro Cultura Litteraria - Wydawnictwo Instytutu Badań Literackich PAN, Warszawa 2013.

2 A. Ubertowska PawełWolski, Tadeusz Borowski-Primo Levi: prze-pisywanie literatury Holocaustu [recenzja], "Zagłada Żydów” 2015 nr 11.

3 D. Szajnert O prze-pisywaniu, "Teksty Drugie” 2016 nr 1. Odwołania do tego tekstu zamieszczam dalej, podając w nawiasie numer strony.

\section{Paweł Wolski -}

doktor, pracuje w Zakładzie Teorii

i Antropologii Literatury Wydziału Filologicznego Uniwersytetu Szczecińskiego, współredaktor czasopism „Autobiografia. Literatura | Kultura | Media" oraz "Narracje o Zagładzie", autor rozprawy Tadeusz Borowski - Primo Levi. Prze-pisywanie literatury Holocaustu (IBL, Warszawa 2014). W przygotowaniu: Tadeusz Borowski. Ciało oraz O zarabianiu w pysk. Boks i ekonomia w literaturze polskiej od międzywojnia do dziś. Kontakt: pawel.wolski@univ. szczecin.pl. 
Szczególnie zaciekawiła mnie część dotycząca Leviego i nieznanej mi włoskiej recepcji badawczej jego pism. W lekturze tej przeszkadzała mi jednak nie tylko, charakteryzująca całość wypowiedzi, meandryczność wywodu, liczne ekskursy, powtórzenia i nieprzejrzysta kompozycja, ale też - przede wszystkim - brak zaufania do autora [czyli Leviego - przyp. P.W.], niewiara w rzetelność zaproponowanej przez niego relacji. (240)

Badaczkę rzeczywiście interesuje przede wszystkim Levi ${ }^{4}$, któremu ja, podejrzliwie czytając jego dzieła, nie zawsze ufam. Na przykład wtedy, gdy przedstawia swoją pierwszą książkę jako „obiektywne studium niektórych aspektów duszy ludzkiej"', a ja uparcie przypominam, że wypowiadał się też o niej jako o zrodzonej z „somatycznej potrzeby natychmiastowego przepracowania doświadczenia obozu"6 i spisanej „w stanie jakiegoś transu" , a następnie wyciągam z tego przykładu wniosek o dialektycznym oscylowaniu zagładowego świadectwa między postulatami weryfikującej naoczności i obiektywizującego dystansu. Mimo że, jak zauważa Szajnert, Levi „wcale nie ukrywał późniejszej, powolnej pracy nad tekstem, nad «montażem» tworzonych na gorąco fragmentów" (237).

Komentatorka nie tylko jednak skupia się na - jak zaznacza - mniej rozpoznanej „Leviologii”, ale niemal całkowicie odrzuca protezy cudzych, nawet niewłoskojęzycznych komentarzy ${ }^{8}$. A mogłaby się na nich wesprzeć, tak jak czyni to, gdy sporadycznie przyjdzie jej odnieść się do Borowskiego'. Mogłaby

4 W całym artykule paralelnie przeze mnie omawiane zagadnienia dotyczące pisarstwa obu są wprowadzane ich zarysowaniem w odniesieniu do Borowskiego i komentowane dopiero na przykładzie Leviego (jak w przypadku sprawy ich opóźnionych debiutów na s. 236-237 czy "naukowości" ich pisarstwa na s. 239-240).

P. Wolski Tadeusz Borowski - Primo Levi..., s. 271.

6 Tamże.

7 Tamże, s. 204.

8 Mając na uwadze cytowane wcześniej zastrzeżenie badaczki, w niniejszej odpowiedzi będę się odwoływać jedynie do niewłoskojęzycznych komentarzy do pisarstwa Leviego. Włoskie głosy w debacie wokół Leviego pojawiają się tu tylko o tyle, o ile zawierają je przywoływane przeze mnie lub Szajnert fragmenty mojej rozprawy.

9 Np. gdy na stronie 235 komentuje moją wzmiankę o nieobecności u obu pisarzy motywu Zagłady jako doświadczenia przede wszystkim żydowskiego, twierdzi, że "takich enuncjacji, odnośnie do Borowskiego, oczekiwał też zapewne - choć z zupełnie innych, lepiej uzasadnionych powodów - Henryk Grynberg (zob. Obsesyjny temat, w: tegoż Prawda nieartystyczna, Almapress, Czeladź 1990, s. 131)". 
np. przywołać wydaną prawie dwie dekady temu nakładem Państwowego Muzeum Oświęcim-Brzezinka Rozmowę z Primo Levim przeprowadzoną przez Ferdinando Camona ${ }^{10}$, która świetnie ilustruje jej komentarz i którą zresztą przytaczam w cytowanym przez nią fragmencie książki ${ }^{11}$. Nie jest to, rzecz jasna, przeoczenie, ale konsekwentny program: nie robi tego, ponieważ pod powierzchnią drobnych zarzutów, takich jak ten, kryje się polemika totalna, która dotyczy nie tylko tego, jak ja przywołuję inne głosy, ale samej zasady mojego ich przywoływania.

Ten wątek mojego wywodu, na który powołuje się w cytowanym fragmencie Szajnert („niespontaniczność” Leviego), jest właściwie powtórzeniem logiki Haydena White'a. O czym badaczka, rzecz jasna, doskonale wie, ponieważ, po pierwsze, tekst ten, inaczej niż głosy z „nieznanej włoskiej recepcji”, został wydany w Polsce $^{12}$, po drugie, sama na White'a się powołuje ${ }^{13}$, a po trzecie, to, że rozwijam w tym wątku jego analizę, sam wielokrotnie zaznaczam w tej tak rzetelnie przez Szajnert przestudiowanej rozprawie. Mimo to badaczka pomija ten kontekst i zmierza do dyskusji nie z głosem, który w tym wątku mojej rozprawy wybrzmiewa, ale ustami, które głos ten przekazują - ze mną. Szajnert nadzwyczaj trafnie wypełnia tym samym ramy gatunkowe tekstu o szczególnym, polemicznym wymiarze, stosując „dokonane $\mathrm{w}$ autobiograficznym nurcie literatury literaturoznawczej odsłonięcie «ja» autorskiego ze wszystkimi jego przypadłościami"14: nie chce dyskutować z tekstem, który zapośrednicza głos White’a, Iana Thomsona ${ }^{15}$ czy

10 „Kiedy w roku 1958 publikował ją [powieść Czy to jest człowiek - przyp. P.W.] Einaudi, dołączyłem rozdział o inicjacji, którego nie ma w wersji wydrukowanej u Da [sic!] Silvy, dopisałem jeszcze wiele rzeczy [...]" (F. Camon Rozmowa z Primo Levim, przeł. E. Kabatc, Państwowe Muzeum Oświęcim-Brzezinka, Oświęcim 1997, s. 55).

11 W toku krytyki Szajnert cytuje stronę 204 mojej rozprawy, ja przywołuję rozmowę Leviego z Camonem na s. 200.

H. White Realizm figuralny w literaturze świadectwa, przeł. E. Domańska. „Literatura na Świecie” $2004, \mathrm{nr} 1 / 2$.

Choć bez podania konkretnego adresu (D. Szajnert O prze-pisywaniu..., s. 233).

14 D. Ulicka Ja czytam moje czytanie, w: Narracja i tożsamość (II), red. W. Bolecki. R. Nycz, Wydawnictwo Instytutu Badań Literackich PAN, Warszawa 2004, s. 177.

Jeden z najczęściej cytowanych niewłoskojęzycznych komentatorów Leviego pisze o tym tak: "Levi stworzył sobie później wokół Czy to jest człowiek coś w rodzaju legendy. Twierdził, że książka została napisana w szale natychmiast po powrocie z tułaczki. W rzeczywistości pracę nad nią zaczął właściwie dopiero szesnaście tygodni po przyjeździe" (I. Thomson Primo Levi. A Life, Picador, New York 2014, s. 29; książka jest dostępna na portalu google.books.com). 
z jakąkolwiek zresztą "przypisową" wypowiedzią w tekście, ale z tekstu tego autorem.

Takie performatywne, totalne zastosowanie się do reguł gatunku jest dla mnie cenne podwójnie. Nie tylko bowiem pozwala mi obserwować w praktyce (i uczyć się), jak działa akademicki dyskurs zdiagnozowany przez Danutę Ulicką (Macieja Michalskiego ${ }^{16}$, Małgorzatę Judę-Mieloch ${ }^{17}$ ), ale do tego jakby podskórnie i, być może, niezamierzenie, dowodzi jednej z tez mojej książki: że dyskurs Zagłady - literacki i akademicki - domaga się szczególnej formy autorstwa, tworzącej zarazem iluzję obiektywizującego dystansu i weryfikującego go „osobistego" doświadczenia - czyli takiej, jaką widziałem w cytowanym przez Szajnert fragmencie o Levim. I że dotyczy to również pisania o pisarstwie Zagłady, a nawet pisania o pisaniu o pisarstwie Zagłady (czyli pisania Szajnert o moim pisaniu o pisarstwie Leviego).

W przypadku tekstu Szajnert cały jednak kłopot z podejścia tego „wszystkimi przypadłościami”. Hipoteza, którą autorytarnie stawia krytyczka, opiera się nie na porządku wpisanym w rozprawę Tadeusz Borowski - Primo Levi. Prze-pisywanie literatury Holocaustu, lecz na porządku równie autorytarnie przypisanym jej przez lekturę Szajnert, a więc stanowiącym swoistą alegorię czytania. Nie jest to praktyka zaskakująca, tyle że zamiast, jak de Man, szukać pominięć, przesunięć itp. w czytanym przez siebie tekście, badaczka pomija własne w czytaniu tych odczytań pominięcia, przeinaczenia i przesunięcia, fikcjonalizujące (w sensie dopowiadania okoliczności prawdopodobnych, ale nieznanych) porządek mojego wywodu. Jednym z nich jest właśnie wspomniany wątek „naukowości” czy „literackości”, w którym Szajnert chce widzieć moją opowieść „o sprzecznościach podważających wartość autokomentarzy Leviego” (238). Ja zaś nie tylko dążę wyraźnie do celu całkiem odmiennego, ale robię to na płaszczyźnie zupełnie odmiennej ontologii lektury. Na stronach 211-212 (a zatem zaledwie kilka stron za cytowanym przez nią fragmentem) piszę bowiem tak: „Nie będzie więc miało żadnego znaczenia to, że Levi nie napisał wersji 1958 Czy to jest człowiek «w ciagu zaledwie kilku miesięcy" ${ }^{\mathbf{1 8}}$ «w jakimś transie» ${ }^{\mathbf{1 9}} \mathrm{i}$ że zaraz po tym nie oddał druku pachnącego

16 M. Michalski Filozof jako pisarz, słowo/obraz terytoria, Gdańsk 2010.

17 M. Juda-Mieloch Na ramionach gigantów Figura autorytetu w polskich tekstach literaturoznawczych, Universitas, Kraków 2009.

F. Camon Rozmowa..., s. 54.

19 Fragment wywiadu z autorem zamieszczonego w: "Mondoperaio”, marzo 1984, n. 3. Cyt. za: A. Minisci Primo Levi e la memoria della Shoah, Alpha Test, Milano 2006, s. 23. 
jeszcze tuszem maszyny do pisania w postaci, jaką znamy dziś", ponieważ moim zamiarem, dowodzę dalej, jest ukazanie, jak to w wyniku zmagań Leviego (czy Borowskiego i innych autorów literatury Zagłady) z (nie)możliwościami literackiej reprezentacji Holocaustu wykuwał się ten szczególny typ pisarstwa, jakim jest świadectwo Zagłady, i jak, w związku z tym, czytamy je dziś. Czyli że nie jest dla mnie najważniejsze w tej akurat rozprawie, czy Levi mylił się, czy nie mylił w autokomentarzach do swojego pisarstwa (ich falsyfikowalność w ogóle nie jest adekwatną kategorią), tylko jak to pisarstwo określało autokomentarzy tych ramy.

Częścią ram określających nasze pojmowanie literatury Zagłady są także narosłe na nich komentarze badaczy (Thomsona, White'a itd.) - czyli wspomniane wcześniej głosy „przypisowe”. Których, jako się rzekło, Szajnert uwzględniać nie może: ,auktorialny przypis może się wydawać dziwacznym lub transgresywnym wystrzałem z referencjalnego pistoletu w czasie fikcjonalnego koncertu"20, jak ujmował to Gérard Genette. Alegorie czytania Szajnert, wytwarzając właśnie takie fikcjonalne lektury, realizują więc inne rozpoznanie de Mana, mówiące, że „retoryka w sposób radykalny zawiesza logikę i otwiera zawrotne możliwości aberracji referencjalnej"21. Wola akademickiej mocy Szajnert sprowadza tym samym naszą dyskusję do psychomachii naukowych, narracjotwórczych osobowości ${ }^{22}$, tracących tożsamość w akcie „aberracyjnych referencji”. A ja, niczym Marsjasz, przegrywam tę Genettowsko-de Manowską konfrontację w agonie fikcjonalnego koncertu, ponieważ powołując się na badaczy (i nadużywając ich), „dziwacznie” wystrzelam z referencjalnego pistoletu, Szajnert zaś, nie powołując się, nie wystrzela i nie nadużywa.

Zacytowałem przed chwilą prowadzącego mnie do tej diagnozy Genette'a za tekstem Przyczynek do przypisologii literackiej Szajnert. Autorka, badając w nim przypisy Miłosza do jego Traktatu poetyckiego z moim komentarzem, komentuje komentarz doń Ewy Bieńkowskiej, dodając ironicznie jeszcze i komentarz taki: „Zrazu wydaje się, że drażni ją [Bieńkowską - przyp. P.W.]

20 G. Genette Les notes, w: tegoż Seuils, Editions du Seuil, Paris 1987, s. 307, za: D. Szajnert Przyczynek do przypisologii literackiej, w: Dzieła, języki, tradycje, red. W. Bolecki, R. Nycz, Wydawnictwo IBL PAN, Warszawa 2006, s. 127.

21 P. de Man Alegorie czytania. /ęzyk figuralny u Rousseau, Nietzschego, Rilkego i Prousta, przeł. A. Przybysławski, Universitas, Kraków 2004, s. 22.

22 W sposób dobrze już zdiagnozowany (i praktykowany), patrz np. A. Zybertowicz Przemoc i poznanie: Studium z nie-klasycznej socjologii wiedzy, Wydawnictwo UMK, Toruń 1995. 
przede wszystkim oczywistość informacji podanych przez Miłosza (cennych być może dla obcych, ale przecież nie «dla nas»)"23. Przywołuję ten właśnie wyimek, ponieważ pobrzmiewa w nim jeszcze bardziej kunsztowny, niż przedstawiłem to przed chwilą, ambiwalentny stosunek Szajnert do autonomii literaturoznawczego głosu, który zresztą wyraziła także w odniesieniu do mojej książki:

Wolski - jak niemal wszyscy badacze zajmujący się literaturą Zagłady - po raz kolejny omawia tu kwestie [„o problemach z jednoznacznym wskazaniem tego, co może być uznawane za literaturę Holokaustu", jak wcześniej ujmuje to badaczka - przyp. P.W.] wielostronnie, rzetelnie, wnikliwie relacjonowane i problematyzowane również przez polskich literaturoznawców [...]. Książka jest wszakże adresowana do profesjonalistów, wystarczyłoby zatem, miast powtarzać rzeczy dobrze znane, zasygnalizować, że ma się świadomość związanych z tematem komplikacji czy aporii, i odesłać czytelników do odpowiednich tekstów, figurujących przecież w bibliografii.

Szajnert na chwilę czyni mnie w tych słowach poprawnym członkiem akademickiej wspólnoty, do jakiegoś przynajmniej stopnia stosującym reguły "przypisologii” (,jak niemal wszyscy badacze zajmujący się literaturą Zagłady"), ale, jednocześnie, członkiem nieco schizofrenicznym: jestem bowiem świadom reguł tych powszechnego obowiązywania (skoro cytuję i się odwołuję, to mam „świadomość związanych z tematem komplikacji”), jak i zupełnie nieświadom ich zbędności („Książka jest wszakże adresowana do profesjonalistów"). Zupełnie jak Bieńkowska, która w odczytaniu Szajnert dowodzi zbędności przypisów Miłosza (są, być może, cenne, „ale przecież nie «dla nas»"), ale nie wie przy tym, że ten język przypisów wcale zbędny nie jest, ponieważ pomaga, „I to pomaga samej autorce, która parę razy wykorzystuje ten komentarz - jawnie (trochę się przy tym krygując), by uwierzytelnić swój bardzo przy tym interesujący (!) wywód, i w sposób utajony" ${ }^{24}$.

Johnathan Culler pisał, że tekst budzi zainteresowanie literackie, kiedy nasze zainteresowanie nim samym przewyższa zainteresowanie ustaleniem

D. Szajnert Przyczynek..., s. 148.

24 Tamże, s. 148 (nawiasowy wykrzyknik oryginalny). 
intencji autorskiej ${ }^{25}$. Dla Szajnert zarówno wywód Bieńkowskiej, jak i dyskurs krytyczny wokół Leviego - zarówno ten nieznany (gdy pisany po włosku), jak i intencjonalnie pomijany (nawet gdy funkcjonuje w językach innych niż włoski, jak w przypadku White’a czy Camona) lub też krytykowany (w odniesieniu do mojej książki) są natomiast „interesujące” (wyjątkowo, ponieważ z nawiasowym wykrzyknikiem) czy „fascynujące” (240) tylko z powodu intencji autorskiej. Jestem wdzięczny komentatorce za wnikliwą lekturę mojego przyczynku do tematu, mimo tej krytyki, w tym za wiele cennych szczegółowych uwag pod jego adresem ${ }^{\mathbf{2 6}}$. Jeśli jednak miałbym naprawiać jej (książki) błędy, zacząłbym od tych, które sprawiają, że czytelnicy tak rzetelni i tak kompetentni jak Danuta Szajnert nie zauważają wpisanego w nią fundamentalnego rozróżnienia na doświadczenie Zagłady i jego reprezentację. Jest to zjawisko wynikające często z okoliczności, która jest jednym z tematów mojej rozprawy: swoiście pojętego etycznego imperatywu, domagającego się "prawdziwej prawdy” i piętnującego jakiekolwiek „frywolności”. Właśnie o frywolność w ostatnich zdaniach artykułu oskarża mnie Szajnert, mając mi za złe np. tytuły podrozdziałów, takie jak Gatunek Zagłady czy zagłada gatunków albo Żyd-ulotny gaz. W tym wypadku to właśnie chyba ten imperatyw „zawiesza logikę i otwiera zawrotne możliwości aberracji referencjalnej" i każe zapominać, że tytuły takie jak te (np. Zbędny Żyd i karzący piorun ${ }^{27}$, Oswajanie Zagłady ${ }^{\mathbf{2}} .$. ), są nawiązaniami: pierwszy do znanego artykułu Stanisława Balbusa $^{29}$, mówiącego m.in. o zmąceniu granic międzygatunkowych (które ja tropię w literaturze Holokaustu), drugi zaś do debaty wokół skandalizują-

25 A właściwie parafrazował tak Literary Interest: The Limits of Anti-Formalism Stevena Knappa, sięgając po jego wypowiedź w wątku książki dotyczącym tego, jak literatura splata jednostkowość z typowością (J. Culler Literatura w teorii, Universitas, Kraków 2013, s. 40), czyli tezy i mi przyświecającej, choć, rzecz jasna, przeze mnie formułowanej w sposób dalece mniej doskonały.

Pomijam w tym miejscu szczegółowe odpowiedzi na większość z nich. Są jednak na tyle inspirujące i istotne z perspektywy badań nad literaturą Holokaustu, że postaram się je skomentować w najbliższym czasie w medium zajmującym się przede wszystkim tym rodzajem pisarstwa.

27 To tytuł drugiego podrozdziału drugiej części w: G. Niziołek Polski teatr Zagłady, Instytut Teatralny im. Zbigniewa Raszewskiego - Wydawnictwo Krytyki Politycznej, Warszawa 2013.

28 Taki tytuł nosi trzeci rozdział w: B. Krupa Opowiedzieć Zagładę: polska proza i historiografia wobec Holocaustu (1987-2003), Universitas, Kraków 2013.

29 S. Balbus „Zagłada gatunków”, w: Polska genologia literacka, red. D. Ostaszewska, R. Cudak, PWN, Warszawa 2007. 
cego porównania piemonckich Żydów do gazu w Argonie z Układu pierwiastków Leviego $^{30}$. A jeśli zgodzić się z Robertem Gordonem, że ironia i autoironia to podstawowe tropy w twórczości Leviego i że pozostają one w ścisłym związku z etycznym wymiarem jego pisarstwa ${ }^{31}$, być może okazałoby się też, że moja „frywolność” jest zaledwie powtórzeniem „frywolności” Leviego. A zatem że Szajnert - stwierdzam na koniec z pokorą - ma rację: jakkolwiek będę czytał literaturę Zagłady i jakkolwiek niezgodne z moimi intencjami rozumienie tej lektury zaproponują mi komentatorzy - i tak nie ucieknę od powrotu do intencji nawet najfrywolniej czytanych przeze mnie pisarzy. Tyle tylko, że w odróżnieniu od badaczek i badaczy tak doświadczonych, jak Danuta Szajnert, ja muszę kroczyć ścieżką dłuższą i bardziej krętą, prowadzącą nie wprost to spotkania dwóch autorskich intencji (np. Szajnert i Leviego), ale przez zaułki, w których kryje się White, Thomson, Lang i włoskojęzyczni krytycy. Którzy, notabene, jakoś chyba jednak naszą wizję tej intencji współtworzą.

To szokujące zestawienie było zamierzone już przez Leviego i dyskutowane z Italo Calvino (piszę o tym na stronach 295-296 mojej rozprawy).

31 R. Gordon "Per mia fortuna...": Irony and Ethics in Primo Levi's Writing, "The Modern Language Review" 1997 No. 2. 


\section{Abstract}

\section{Paweł Wolski}

UNIVERSITY OF SZCZECIN

On Intentions, Footnotes and Trans-Scribing (In Response to Danuta Szajnert)

Wolski polemicizes with Danuta Szajnert, who reviewed his book Tadeusz BorowskiPrimo Levi: Prze-pisywanie literatury Holocaustu [Tadeusz Borowski - Primo Levi: TransScribing Holocaust Literature] ('O prze-pisywaniu' [On Trans-Scribing], Teksty Drugie, 1 (2016). While he agrees with many of Szajnert's remarks, Wolski highlights a fundamental epistemological discrepancy between his position and Szajnert's: Szajnert suggested that he falsely attributes intentions to Borowski and Levi. In fact, as Wolski argues here, his book aimed to shed light on the process through which readers form ideas about these authors' intentions. For Wolski, the difference between these two aspects might be rooted in the ethical imperative that characterized earlier Holocaust literature - an imperative that annulled the dichotomy between representation and the represented (as well as the analogona of that dichotomy).

\section{Keywords}

Holocaust literature, intention, attribution, polemics 